\title{
Regional Environmental Supervision And Corporate Environmental Investment: From The Perspective of Ecological Damage Compensation
}

Huixiang Zeng

Central South University

Chen Cheng

Central South University

Youliang Jin

Central South University

Qiong Zhou ( $\nabla$ zhouqiong2020@csu.edu.cn)

Central South University https://orcid.org/0000-0002-7530-8144

\section{Research Article}

Keywords: compensation system, corporate environmental investment, regional environmental supervision, market degree, firm ownership

Posted Date: August 4th, 2021

DOI: https://doi.org/10.21203/rs.3.rs-684347/v1

License: (9) This work is licensed under a Creative Commons Attribution 4.0 International License. Read Full License

Version of Record: A version of this preprint was published at Environmental Science and Pollution Research on January 6th, 2022. See the published version at https://doi.org/10.1007/s11356-021-184681. 


\section{Abstract}

Based on the "Pilot Reform of the Compensation System for Ecological and Environmental Damage" launched in 2015 and a research sample of listed companies in China's heavy pollution industry from 2014 to 2017, this paper uses a difference-in-differences model to empirically test the impact of the compensation system on corporate environmental investment, as well as the moderating effect of market degree and firm ownership. The result shows that the implementation of the compensation system has significantly promoted corporate environmental investment, and the market degree has a moderating effect, but the supervision effect remains the same due to firm ownership. Local government's strict environmental supervision on local enterprises is the important channel to ensure the function of ecological damage compensation system. This research provides a reference for the national government to formulate specific and effective environmental policies, stimulate the environmental governance motivation of local governments, and encourage enterprises to assume environmental responsibilities, to achieve green and sustainable development.

\section{Highlights}

- Ecological compensation system can improve the intensity of regional environmental supervision.

- The implementation of the compensation system can effectively promote corporate environmental investment.

- The increase of corporate environmental investment in high-marketization areas is significantly higher than that in low-marketization areas.

- The increase of state-owned enterprises' environmental investment is not significantly higher than that of non-state-owned enterprises

\section{Introduction}

In recent years, the global ecological environment has been seriously damaged. Environmental problems emerge in an endless stream, including poor air quality, soil heavy metals that exceed the standard, water quality deterioration and many other problems. With the increasingly serious ecological damage problem and public awareness of environmental protection, governments pay increasing attention to environmental protection. At present, the focus of environmental pollution control is to increase investment in environmental protection, reduce excessive emissions of pollutants from the source.

Enterprise is a very important part of a country's economic structure, enterprises can create a large amount of material wealth for our society through production and operation activities. However, it is inevitable to adversely affect the environment, such as discharge sewage, consume and use natural resources excessively (Fabian 2015; Jin et al. 2019; Zhang et al. 2020). According to the principle of "who pollutes, who controls" in "Environmental Protection Law", enterprises should assume the main responsibility of environmental protection and increase environmental investment. 
However, in the short term, the main beneficiary of corporate environmental investment (CEI) is society rather than the enterprise itself. For rational managers, it is difficult to use limited resources for environmental investment with low economic benefits and high uncertainty for the future (Walker et al. 2018). The obvious "altruist non-self-interest" characteristic of CEl inevitably promotes externally solving environmental problems at the institutional constraint level.

In recent years, governments have gradually strengthened the construction of environmental laws and regulations, attached importance to the assessment of the environmental performance of local governments, been required to strictly supervise and deal with environmental pollution, and promoted corporate green development. However, corporate profit-based activities are conducive to promoting local economic growth and achieving the government's goals and individual utility of local officials. As a result, local governments may lack the incentive to regulate the environment, they are unwilling to implement environmental policies that may indirectly lead to reduced fiscal revenues and relax regulations on corporate environmental pollution (Jiang, Lin, and Lin 2014).

The construction of the compensation system for ecological and environmental damage is an important environmental protection measure, it gives full consideration to the regulatory effectiveness of local governments. This system has changed the traditional problem of "corporate pollution, mass victimization, government pay" and adhered to the principle of "polluter pays" (Wang 2018). Developed countries such as the United States, France and Japan are typical representatives of restoring ecological environments through damage compensation, and their successful experiences have also provided valuable lessons and references for the construction of ecological civilizations in other countries. On December 3, 2015, the general office of the CPC Central Committee and the general office of the State Council issued the "Pilot Reform of the Compensation System for Ecological and Environmental Damage", and began to carry out the reform pilot work in seven provinces and cities. The system clearly shows that the income of ecological damage compensation becomes the financial revenue of local government, and requires local government to make relevant data public and social media in real time. The paper, with the characteristics of "compensation income + external supervision", encourages local governments to strengthen regional environmental supervision, so as to change the situation of complete policy release but lack of implementation effectiveness. The 38th meeting of the central leading group for comprehensive deepening reform held on August 29, 2017 passed the reform plan of ecological environment damage compensation system, and began to implement the system nationwide, and accelerate the construction of ecological civilization in China. The question to be concerned in this paper is whether the implementation of this policy has promoted enterprises to increase environmental protection investment?

The study of environmental governance in the field of economics and management mainly focuses on two aspects: First, the impact of environmental regulation on regional or industrial productivity and economic development (e.g., Song et al. 2020; Yu and Shen 2020; Zou et al. 2020; Turken et al. 2019; Knellera and Manderson 2012), and second, the impact of external regulation and the characteristics of enterprise engaging in corporate environmental behaviour (e.g., Saltari and Travaglini 2011; Gao and 
Zheng 2017; Jiang and Akbar 2018). These studies have yielded fruitful research results. However, we found that few studies discuss macro-governance policies, local government behaviour and microenterprise-level factors in one scenario. Therefore, the first research question of this paper is as follows: Does the implement of the compensation system can enhance regional environmental supervision, and encourage companies to invest more in environmental protection? In addition, China is in a critical period of comprehensive deepening of market-oriented reform, Market degree reflects the institutional environment in different regions to a large extent, it refers to the extent to which markets play a role in resource allocation. Market degree in different regions has significant differences. These differences can affect organizational and individual behaviour to some extent. As an investment behaviour, moral responsibility behaviour, environmental investment will also be affected. At the same time, the characteristics of Chinese enterprises - firm ownership cannot be ignored (Luo and Tang 2009). In view of that, the second research question of this paper is proposed: Will the effect of the compensation system on corporate behaviour vary depending on market degree and firm ownership?

This paper starts from the ecological damage compensation system, study the impact of regional environmental supervision on corporate behaviour. Referring to the practice of most literatures, uses a difference-in-differences model to test the impact. The results show that the implementation of the compensation system can effectively promote environmental investment, and the scale of corporate environmental investment in high-marketization areas is significantly higher, while firm ownership does not show a significant moderating effect.

This work has several notable contributions. First, in the research method, the formation of natural experimental group by using the pilot policy can alleviate the endogenous problems to a large extent. It can not only identify the impact of environmental regulations on environmental investment, but also accurately evaluate the governance effect of the implementation of the policy, and expand the existing research. Second, from the perspective of research, the existing literature mainly studies the impacts of environmental regulation on industrial structure and technological innovation. This paper considers the perspective of the main body of policy implementation, local government, and evaluates the effectiveness of environmental protection policy at the micro level, providing evidence for existing environmental regulation research. Third, the existing literature does not take the impact of external institutional environment on the effectiveness of policy governance into account. This paper considers market degree, regional environmental supervision and corporate environmental investment in one scenario to explore. This paper provides a basis for the central government to formulate targeted environmental policies, encourage local governments to strengthen environmental supervision, and drive enterprises to strengthen their environmental protection behaviour.

The remainder of the paper is organized as follows. Section 2 puts forward the research hypothesis and provides the theoretical analysis and literature review. Section 3 presents the methodology, including the variable settings, sample selection, data source and model design. Section 4 presents the empirical results and analysis and conducts an additional robustness test and endogenous test. Section 6 is the mechanism analysis. Section 6 concludes the paper. 


\section{Theoretical Background And Hypothesis Development}

\subsection{Institutional Background}

Before 2015, governments began to pay attention to environmental pollution. 2015 was a year of outstanding environmental problems in China, and major events such as "the Tianjin bombing"and "the launch of two rounds of red alerts for heavy pollution in Beijing" have aroused high social concern about environmental issues. On December 3, 2015, the General Office of the CPC Central Committee and the State Council issued the "Pilot Reform of the Compensation System for Ecological and Environmental Damage", which was carried out in seven provinces and cities in Jiangsu, Shandong, Hunan, Chongqing, Jilin, Yunnan and Guizhou.

The implementation of the compensation system has a significant impact on environmental supervision in the pilot areas, mainly because of the following characteristics:

(1) local governments have the motivation to fully implement the compensation system and effectively strengthen environmental supervision. With the authorization of the State Council, the pilot local government shall become the right person of ecological environment damage compensation within the administrative area, consult with the compensation obliger on specific issues such as damage repair and liability, and the compensation expenses shall become the local government's fiscal revenue.

(2) Strict external governance will promote local governments to take measures for environmental supervision. The system requires that information such as ecological environment damage assessment, compensation and repair effect report should be made public, to protect the public's right to know. At the same time, the local governments should implement their responsibilities and report to the State Council at the end of August each year on the progress of the pilot work. The Ministry of Environmental Protection, in cooperation with the relevant departments, will conduct a comprehensive assessment of their work.

On the whole, the characteristics of the system of "compensation income + external governance" have encouraged local governments to strengthen regional environmental supervision.

In order to further implement the ecological environment management plan, the 38th meeting of the Central Leading Group for Comprehensive Deepening Reform held on August 29, 2017 adopted the "Programme for the Reform of the Compensation System for Ecological and Environmental Damage" and began to implement the ecological environment damage compensation system nationwide. This widely pursued initiative is more evidence of the effectiveness of the compensation system to some extent.

\subsection{Regional Environmental Supervision and Corporate Environmental Investment}

Porter's hypothesis argues that reasonable environmental regulation not only enhances technological innovation and increases the productivity and competitiveness of enterprises but also reduces the cost of compliance with environmental regulations, enhances the efficient use of resources, and achieves a "win- 
win" for environmental protection and economic growth (Porter and DerLinde 1991; Berman and Bui 1998). However, enterprises are economic subjects in pursuit of maximizing benefits, and environmental investment is an external non-economic project. Although environmental investment can help enterprises build a long-term competitive advantage, it still requires a large amount of money for a long time, and it is difficult to achieve economic benefits in the short term (Bansal and Roth 2000; Lu et al. 2019). According to factor endowment theory, rational managers will strengthen their investments only if the investment income from environmental protection (the cost of environmental pollution) is higher than the corresponding cost of environmental investment (Gray and Deily 1996; Arouri et al. 2012). Under the condition that local governments relax environmental supervision, the cost of environmental pollution is low, and the endowment income obtained through environmental protection cannot cover the corresponding cost, so enterprises lack enthusiasm for environmental investment. At this point, strong external regulation is needed to address the problem related to the externality of the environment. However, local governments show a pattern of competing for economic growth, and the prospects of officials are linked to local economic growth (Zhou 2007; Yao and Zhang 2013). Driven by economic and political forces, local governments have sufficient incentives to relax environmental regulation to seek maximum growth of the regional GDP, and the effectiveness of environmental governance is difficult to guarantee. To improve the implementation and effectiveness of environmental policies, the central government of China has put forward the requirement of "incentive and restraint" in the ecological civilization system, and the compensation system fully reflects this requirement. Therefore, this paper tests whether the compensation system can improve regional environmental supervision and enhance corporate environmental investment.

At present, there are few studies that use environmental policy to measure environmental supervision and study the direct effect of environmental supervision on CEI, but the study of environmental pollution penalties and CEI provides a reference for this paper. The conclusion that there has been a significant increase in environmental investment is widely accepted when environmental penalties are strong enough, but the issue of the "threshold effect" remains controversial. Leiter et al. (2010) used European manufacturing data from 1998 to 2007 and found that pollution penalties showed a significant positive correlation with environmental investment. Liao et al. (2018) used Chinese companies as a sample and reached the same conclusion. Eyraud et al. (2013) further confirmed this correlation in 35 countries. However, Tang (2013) found that there is a "U-shaped" relationship between pollution penalties and CEI, that is, a "threshold effect". In summary, the positive correlation between environmental regulation and environmental investment in the existing literature has been extensively confirmed.

Thus, it is assumed that:

H1: The implementation of the compensation system can effectively promote corporate environmental investment.

\subsection{The Moderating Effect of Market Degree}


Modern enterprises implement a system of entrustment and agency, and managers have the power to make business decisions. Managerial activity is largely influenced by the external environment of the country or region (Baumol 1990; Wang and You 2012). China has made remarkable achievements in its transition from a planned economy to a market economy, but the reform is still in progress, the development of various regions is still different, and the market degree varies from region to region (Cull et al. 2013).

In low-marketization areas, the government has always played a leading role. In high-marketization areas, companies face less regulatory pressure, with higher economic freedom and less government intervention. Managers tend to pay more attention to current performance and allocate more resources to productive activities such as production and research (Fang 2006; He et al. 2016). However, local governments have strengthened environmental regulation, and the original "weak interventions" conducted in high-marketization areas are limited (Kesidou and Demirel 2012). Enterprises must make strategic responses, adjust investment preferences and focus on environmental performance to ease the pressure of legitimacy and meet government requirements

In summary, the strengthening of environmental supervision limits the freedom of enterprises in highmarketization areas, which will be more affected. Enterprises in low-marketization areas that have been consistently subject to higher levels of government intervention will not be seriously affected. Therefore, this paper presents the following hypothesis:

H2: After the implementation of the compensation system, the increase in corporate environmental investment in high-marketization areas is significantly higher than that in low-marketization areas.

\subsection{The Moderating Effect of Firm Ownership}

The influence of the macro-system environment on the behaviour of enterprises is often influenced by enterprises' own nature, and firm ownership characterizes the institutional basis of Chinese enterprises. Studies have shown that there are significant differences in the investment behaviour of state-owned enterprises (SOEs) and non-state-owned enterprises (non-SOEs) (Li et al. 2015; Zhang et al. 2016). There is also a lack of consistency in social responsibility (Wei et al. 2017). Environmental investment is an integral part of corporate investment decisions and an important reflection of environmental responsibility (Chang and Hu 2011). Therefore, we believe that the effect of regional environmental supervision on corporate environmental investment varies for enterprises with different types of firm ownership.

In the past, the Chinese government put economic development ahead of environmental protection, and SOEs have been subjected to "soft constraints" in environmental regulation (Wang and Wheeler 2005). However, in the context of increasingly serious environmental problems, the central government now vigorously promotes green development, and local governments have also strengthened environmental supervision. According to legitimacy theory, the behaviour of enterprises is influenced by external institutional pressures. When an enterprise's environmental behaviour does not meet societal 
expectations or the requirements of policies and regulations, its legitimacy is threatened (Suchman 1995; Zeng et al. 2020). Although China has greatly reduced the proportion of the state-owned system in the national economy, the role of the government in the allocation of resources still cannot be ignored. Resource theory holds that all organizations need to obtain resources from the external environment; therefore, the behaviour of the resource demand side is controlled by the resource allocation side (Mahoney and Pandian 1992; Lo et al. 2012). The government controls SOEs; they often reflect the will of the government and play the role of the government's "image spokesman", so they need to bear more of the policy and social burden (Jin et al. 2019). To meet the government's environmental assessment and society's environmental demands, SOEs will respond to environmental problems more actively and rapidly and take the environment into important consideration in decision-making. The strengthening of regional environmental supervision promotes corporate environmental behaviour at the institutional level and may have a greater effect on SOEs that are overseen by the government. This paper presents the following hypothesis:

H3: After the implementation of the compensation system, the increase in corporate environmental investment of SOEs is significantly higher than that of non-SOEs.

\section{Methodology}

\subsection{Variables}

Regional Environmental Supervision (RES). This paper takes the compensation system as an exogenous measure of regional environmental supervision. Enterprises in pilot areas and after the implementation of the system take 1 , the rest take 0 .

Market Degree. Following the "China Sub-Province Marketization Index Report (2018)" (the book records data only for 2008-2016), this paper measures market degree by the mean of the "Total Marketization Index Score" of each province for 2015-2016.

Firm Ownership. State-owned listed companies are assigned the value of 1 ; otherwise, the value assigned is 0 .

Corporate Environmental Investment (CEI). There have been studies that use environmental investment data disclosed in "Corporate social responsibility reports", "Environmental responsibility reports", and "Sustainable development reports", but the above measurement has a certain degree of subjectivity, and after an independent audit by a third party, the objectivity and reliability of the financial data can be ensured. Therefore, referring to the research of Deng et al. (2019), Xu et al. (2019), Ma and Tang (2018), using data directly related to environmental protection in the breakdown of construction projects in the annual report of listed companies, such as desulfurization projects, out-of-stock projects, sewage treatment, exhaust gases, dust removal, energy conservation and other project, and added them up to obtain the environmental investment for the current year. In order to control the impact of the difference in 
the size of the company, the total assets of enterprises to standardize the amount of environmental investment.

Control Variables. We follow the research of Wei et al. (2017) and Jiang and Akbar (2018), and the control variables selected in this paper are shown in Table 1. In addition, Table 1 summarizes the definitions and measurement methods of all variables.

Table 1 Variable Definitions and Measurements 


\begin{tabular}{|c|c|c|c|c|}
\hline \multicolumn{2}{|c|}{ Variable type } & Variable symbol & Variable name & Variable measurement \\
\hline \multicolumn{2}{|c|}{ Explained variables } & Invest & $\begin{array}{l}\text { Investment in } \\
\text { environmental } \\
\text { protection }\end{array}$ & $\begin{array}{l}\text { Total investment/average total } \\
\text { assets of enterprises }\end{array}$ \\
\hline \multirow{7}{*}{\multicolumn{2}{|c|}{ Explaining variables }} & Treatment & $\begin{array}{l}\text { Policy virtual } \\
\text { variables }\end{array}$ & $\begin{array}{l}\text { The number of enterprises in the } \\
\text { pilot area is } 1 .\end{array}$ \\
\hline & & Time & $\begin{array}{l}\text { Time virtual } \\
\text { variable }\end{array}$ & $\begin{array}{l}\text { After the implementation of the } \\
\text { CSEED is } 1 \text {, before the } \\
\text { implementation of } 0\end{array}$ \\
\hline & & Treatment*Time & $\begin{array}{l}\text { Interactive item } \\
1\end{array}$ & $\begin{array}{l}\text { Interaction of policy virtual } \\
\text { variables and time virtual } \\
\text { variable }\end{array}$ \\
\hline & & MD & Market degree & $\begin{array}{l}\text { The score of regional market } \\
\text { index }\end{array}$ \\
\hline & & MD*Time & $\begin{array}{l}\text { Interactive item } \\
2\end{array}$ & $\begin{array}{l}\text { Interaction of MD and time } \\
\text { virtual variable }\end{array}$ \\
\hline & & FO & Firm ownership & $\begin{array}{l}\text { SOEs take the value of } 1 \text {, and } \\
\text { non-SOEs take the value of } 0 .\end{array}$ \\
\hline & & FO*Time & $\begin{array}{l}\text { Interactive item } \\
3\end{array}$ & $\begin{array}{l}\text { Interaction of FO and time } \\
\text { virtual variable }\end{array}$ \\
\hline \multirow[t]{9}{*}{$\begin{array}{l}\text { Control } \\
\text { variables }\end{array}$} & \multirow[t]{7}{*}{$\begin{array}{l}\text { Company } \\
\text { characteristics }\end{array}$} & Size & $\begin{array}{l}\text { Size of the } \\
\text { enterprise }\end{array}$ & Ln (Total Assets) \\
\hline & & ROA & $\begin{array}{l}\text { Return on } \\
\text { assets }\end{array}$ & Net profit/total assets \\
\hline & & Lev & $\begin{array}{l}\text { Financial } \\
\text { leverage }\end{array}$ & Total liabilities/total assets \\
\hline & & Tobin-Q & $\begin{array}{l}\text { Investment } \\
\text { opportunities }\end{array}$ & $\begin{array}{l}\text { Enterprise market value/asset } \\
\text { replacement cost }\end{array}$ \\
\hline & & Flow & $\begin{array}{l}\text { Operating cash } \\
\text { flow }\end{array}$ & $\begin{array}{l}\text { Net operating cash } \\
\text { flow/average total assets }\end{array}$ \\
\hline & & Age & $\begin{array}{l}\text { Age of } \\
\text { business }\end{array}$ & $\begin{array}{l}\text { Number of years the firm has } \\
\text { been listed }\end{array}$ \\
\hline & & Growth & Ability to grow & $\begin{array}{l}\text { Operating income for the } \\
\text { year/operating income of the } \\
\text { previous year }\end{array}$ \\
\hline & \multirow[t]{2}{*}{$\begin{array}{l}\text { Regional } \\
\text { characteristics }\end{array}$} & GDP & $\begin{array}{l}\text { Economic } \\
\text { situation in the } \\
\text { province }\end{array}$ & Ln (regional GDP) \\
\hline & & Subsidy & $\begin{array}{l}\text { Regional } \\
\text { financial } \\
\text { subsidies }\end{array}$ & Ln (regional financial subsidy) \\
\hline
\end{tabular}




\begin{tabular}{lll} 
Waste1 & $\begin{array}{l}\text { Industrial } \\
\text { wastewater } \\
\text { emissions }\end{array}$ & $\begin{array}{l}\text { Ln (regional industrial } \\
\text { wastewater emissions in the } \\
\text { current year) }\end{array}$ \\
\hline Waste2 & $\begin{array}{l}\text { Industrial } \\
\text { sulphur dioxide } \\
\text { emissions }\end{array}$ & $\begin{array}{l}\text { Ln (regional industrial sulphur } \\
\text { dioxide emissions in the current } \\
\text { year) }\end{array}$ \\
\hline Waste3 & $\begin{array}{l}\text { Industrial soot } \\
\text { emissions }\end{array}$ & $\begin{array}{l}\text { Ln (regional industrial soot } \\
\text { emissions in the current year) }\end{array}$
\end{tabular}

\subsection{Sample and Data}

The compensation system was introduced on December 3, 2015. It has been implemented nationwide since January 1,2018 . Due to the availability of environmental data, this paper considers listed companies in the heavy polluting industry for two years before and after the implementation of the pilot programme to be the research sample. The enterprises in the pilot area are experimental groups, and the enterprises in the non-pilot areas are the control group. The pilot areas are Jiangsu, Shandong, Hunan, Jilin, Yunnan, Guizhou and Chongqing.

Based on the 2008 "Directory of Environmental Protection Verification Industry of Listed Companies by the Ministry of Environmental Protection of China" and the 2010 "Guidelines for Environmental Information Disclosure of Listed Companies", this paper identifies 16 categories of industries, namely, thermal power, steel, cement, electrolytic aluminium, coal, metallurgy, chemicals, petrochemicals, building materials, papermaking, brewing, pharmaceutical, fermentation, textile, tanning and mining as heavy pollution industries. The sample is screened as follows: first, ST, *ST enterprises are excluded; second, enterprises with missing data are excluded, including samples that entered the market after 2014 and enterprises for which the in-building engineering accounts did not provide details. After the above screening process, a total of 412 enterprises and 1648 observation samples were obtained, of which the experimental group contained 552 observation samples and the control group contained 1096 observation samples.

The environmental investment data are collected by hand from the annual reports of enterprises; the marketization data are derived from the "China Sub-Province Marketization Index Report (2018)"; the data on regional environmental pollution stakes are from the "China Environmental Statistics Yearbook", and the data on the other research variables are from the "iFind database" (http://www.51ifind.com/). This paper uses Excel 2019 and Stata 14.0 for data processing.

\subsection{Model}

To examine the impact of regional environmental supervision on corporate environmental investment, this paper uses a difference-in differences model. Since the parallel trend hypothesis is an important prerequisite for the use of the model (Lu and Ling 2017; Hsueh 2019), this paper compares corporate environmental investment in pilot areas (experimental groups) and non-pilot areas (control groups) before and after the compensation system (2015). As shown in Fig. 1, the trends of environmental 
investment in the two groups were basically the same before 2015 . However, the trends began to show a significant difference after 2015. Therefore, this paper successfully addresses the parallel trend hypothesis, and the setting of the difference-in differences model is reasonable. Figure 2 shows the impact of market degree on corporate environmental investment before and after the compensation system. It can be found that the level of environmental investment of both groups in the pilot areas has been improved, but the increase in the environmental investment of enterprises in the high-marketization areas was higher. The results of the examination on the impact of firm ownership on environmental investment are shown in Fig. 3. The environmental investment of SOEs also saw a greater degree of growth. The preliminary examination of the moderating effect of market degree and firm ownership cannot be rejected.

This paper employs the following difference-in-differences model:

Invest $=a+\beta_{1}$ Treated $+\beta_{2}$ Time $+\beta_{3}$ Treated $\times$ Time $+\beta_{4}$ Controls $+\varepsilon$ (1)

Invest is corporate environmental investment, which is standardized by the total assets. Treated indicates, enterprises in pilot areas with the value " 1 " and non-pilot areas with the value " 0 ". Time is the implementation of the compensation system, after 2015 this variable takes the value of " 1 ", and before 2015 , this variable takes the value of " 0 ". Controls represents the control variables. $a$ is the intercept term, and $\varepsilon$ is the error term.

Our primary focus is $\beta_{3}$, the coefficient estimate of the interaction between Treated and Time. A positive significant $\beta_{3}$ in formula (1) would be evidence supporting $\mathrm{H} 1$.

To explore the moderating effect of market degree and firm ownership further, the following test model is set up for the experimental group:

Invest $=a+\beta_{7} M D+\beta_{2}$ Time $+\beta_{3} M D \times$ Time $+\beta_{4}$ Controls $+\varepsilon$ (2)

Invest $=a+\beta_{1} F O+\beta_{2}$ Time $+\beta_{3} F O \times$ Time $+\beta_{4}$ Controls $+\varepsilon$ (3)

In formula (2), MD is the market degree in the pilot areas. In formula (3), FO is firm ownership, SOEs take the value of " 1 ", and non-SOEs take the value of " 0 ".

\section{Empirical Results And Analysis}

\subsection{Descriptive Statistics}

Table 2 reports the descriptive statistics of the main variables. The average value of the standardized value for corporate environmental investment is 0.0021 , the maximum value is 0.1567 , the minimum value is as low as 0 , and the level of environmental protection investment between enterprises varies greatly. The average value of Treated is 0.3350 , indicating that $33.50 \%$ of the enterprises are affected 
by the compensation system, and enterprises in pilot areas accounted for approximately one-third of the total sample.

Table 2 Basic descriptive statistics

\begin{tabular}{lllllll} 
Variable & Observations & Average & Median & $\begin{array}{l}\text { Standard } \\
\text { deviation }\end{array}$ & Minimum & Maximum \\
\hline Invest & 1648 & 0.0021 & 0.0000 & 0.0107 & 0.0000 & 0.1567 \\
\hline Treated & 1648 & 0.3350 & 0.0000 & 0.4721 & 0.0000 & 1.0000 \\
\hline Time & 1648 & 0.5000 & 0.5000 & 0.5002 & 0.0000 & 1.0000 \\
\hline Treated*Time & 1648 & 0.1675 & 0.0000 & 0.3735 & 0.0000 & 1.0000 \\
\hline Size & 1648 & 22.3983 & 22.2424 & 1.0713 & 19.0976 & 26.6068 \\
\hline ROA & 1648 & 0.0731 & 0.0656 & 0.1091 & -0.8594 & 0.7086 \\
\hline Lev & 1648 & 0.4176 & 0.4085 & 0.1909 & 0.0120 & 1.0373 \\
\hline Tobin-Q & 1648 & 0.3607 & 0.3380 & 0.1755 & 0.0316 & 1.6237 \\
\hline Flow & 1648 & 0.0578 & 0.0571 & 0.0674 & -0.2603 & 0.4841 \\
\hline Age & 1648 & 14.9551 & 15.0000 & 5.8536 & 4.0000 & 27.0000 \\
\hline Growth & 1648 & 1.2721 & 1.0905 & 1.9078 & 0.1530 & 59.7053 \\
\hline GDP & 1648 & 10.4718 & 10.5187 & 0.7405 & 6.8253 & 11.4043 \\
\hline Subsidy & 1648 & 5.1492 & 5.1408 & 0.5126 & 3.1476 & 6.1278 \\
\hline Wasted1 & 1648 & 11.1401 & 11.3044 & 1.0560 & 5.2883 & 12.2304 \\
\hline Wasted2 & 1648 & 12.6299 & 12.8712 & 1.1538 & 6.2519 & 14.1222 \\
\hline Wasted3 & 1648 & 12.3842 & 12.5917 & 1.1437 & 4.8752 & 14.8926 \\
\hline & & & & & & \\
\hline
\end{tabular}

Table 3 provides the results of the analysis of the differences before and after the compensation system. As seen from Panel A, after the implementation of the compensation system, there was no significant change in corporate environmental investment in the non-pilot areas, while investment in the pilot areas rose from 0.0005 to 0.0013 . That is, the implementation of the compensation system has a significant effect on corporate environmental investment. According to Panel $B$, the added value of corporate environmental investment in the high-marketization areas is higher than that in the low-marketization areas by 0.0020 , which means the compensation system has a larger effect on corporate environmental investment in high-marketization areas. The results of Panel $\mathrm{C}$ also show that the increase in the environmental investment of SOEs is higher than that of non-SOEs. The above statistical analysis results support the original hypothesis. 
Table 3 Difference statistics before and after the compensation system

Panel A: All-Sample

\begin{tabular}{lllll} 
& N & Before the policy & After the policy & Difference \\
\hline Experimental Group (Pilot Areas) & 552 & 0.0005 & 0.0018 & 0.0013 \\
\hline Control Group (Non-pilot Areas) & 1096 & 0.0027 & 0.0026 & -0.0001 \\
\hline Difference-in-differences & & & & 0.0014 \\
\hline
\end{tabular}

Panel B: CEl in Enterprises in Pilot Areas (Experimental Group)

\begin{tabular}{lllll} 
& $\mathrm{N}$ & Before the policy & After the policy & Difference \\
\hline Enterprises in High-marketization Areas & 240 & 0.0004 & 0.0029 & 0.0025 \\
\hline Enterprises in Low-marketization Areas & 312 & 0.0005 & 0.0010 & 0.0005 \\
\hline Difference-in-differences & & & & 0.0020
\end{tabular}

Panel C: CEI in Enterprises in Pilot Areas (Experimental Group)

\begin{tabular}{lllll} 
& N & Before the policy & After the policy & Difference \\
\hline SOEs & 164 & 0.0002 & 0.0020 & 0.0018 \\
\hline Non-SOEs & 388 & 0.0006 & 0.0014 & 0.0008 \\
\hline Difference-in-differences & & & & 0.0010
\end{tabular}

\subsection{Hypothesis Test}

\subsubsection{Main Effect Test}

Table 4 reports the basic test results of the implementation of the compensation system and environmental investment. Column (1) does not include control variables and year fixed effectDindustry fixed effects and region fixed effects, the results are not significant. After adding the control variable, the coefficient of Treated $\times$ Time in column (2) is 0.0018 and significantly positive at the $5 \%$ level. After considering the fixed effect in column (3), the significance is further improved. After the implementation of the compensation system, compared with unaffected enterprises (non-pilot area enterprises), the level of environmental investment of enterprises in the pilot areas has been significantly improved, $\mathrm{H} 1 \mathrm{has}$ been supported.

Table 4 Main Effect Test 


\begin{tabular}{|c|c|c|c|}
\hline \multirow[t]{2}{*}{ Variable } & \multicolumn{3}{|l|}{ Invest } \\
\hline & Q10 & \2】 & $\varangle 3 \rrbracket$ \\
\hline \multirow[t]{2}{*}{ Treated } & 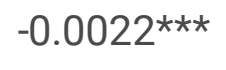 & 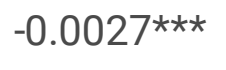 & $-0.0026 * * *$ \\
\hline & $(-2.84)$ & $(-3.23 \rrbracket$ & $(-3.12)$ \\
\hline \multirow[t]{2}{*}{ Time } & -0.0002 & 0.0007 & -0.0001 \\
\hline & $(-0.79 \rrbracket$ & $(0.88 \rrbracket$ & $(-0.08)$ \\
\hline \multirow[t]{2}{*}{ Treated*Time } & 0.0015 & $0.0018^{\star \star}$ & $0.0018 * \star *$ \\
\hline & $(1.35 \rrbracket$ & $(2.18 \rrbracket$ & $(3.14)$ \\
\hline \multirow[t]{2}{*}{ Size } & & $0.0013^{\star \star \star}$ & $0.0008 * \star$ \\
\hline & & $(4.36)$ & $(2.37)$ \\
\hline \multirow[t]{2}{*}{ ROA } & & -0.0031 & -0.0006 \\
\hline & & $(-1.17)$ & $(-0.23)$ \\
\hline \multirow[t]{2}{*}{ Lev } & & $0.0053^{\star \star \star}$ & 0.0030 \\
\hline & & $(2.78)$ & $(1.54)$ \\
\hline \multirow[t]{2}{*}{ Tobin-Q } & & -0.0003 & 0.0014 \\
\hline & & $(-0.12 \rrbracket$ & $(-0.65)$ \\
\hline \multirow[t]{2}{*}{ Flow } & & $0.0071^{\star}$ & 0.0022 \\
\hline & & $(1.69)$ & $(0.51)$ \\
\hline \multirow[t]{2}{*}{ Age } & & -0.0000 & 0.0000 \\
\hline & & $(-0.14 \rrbracket$ & $(0.06)$ \\
\hline \multirow[t]{2}{*}{ Growth } & & -0.0002 & -0.0001 \\
\hline & & $(-1.33 \rrbracket$ & $(-0.07)$ \\
\hline \multirow[t]{2}{*}{ GDP } & & $-0.0027 * \star$ & $-0.0021^{\star}$ \\
\hline & & $(-2.19 \rrbracket$ & $(-1.65)$ \\
\hline \multirow[t]{2}{*}{ Subsidy } & & 0.0012 & 0.0012 \\
\hline & & $(1.15)$ & $(1.14)$ \\
\hline \multirow[t]{2}{*}{ Wasted1 } & & 0.0000 & -0.0006 \\
\hline & & $(0.03)$ & $(-0.65)$ \\
\hline Wasted2 & & -0.0008 & -0.0006 \\
\hline
\end{tabular}




\begin{tabular}{llll}
\hline Wasted3 & & $0.0022^{\star \star \star}$ & $0.0020^{\star \star \star}$ \\
\hline Intercept & 0.0027 & $-0.0243^{\star *}$ & $-0.0283^{\star}$ \\
\hline & $(5.98)$ & $(-2.68)$ & $(-1.75)$ \\
\hline Year & NO & NO & YES \\
\hline Industry & NO & NO & YES \\
\hline Region & NO & NO & YES \\
\hline Sample size & 412 & 412 & 412 \\
\hline Observations & 1648 & 1648 & 1648 \\
\hline R2 & $5.70 \%$ & $7.07 \%$ & $11.24 \%$
\end{tabular}

Note. T statistics are shown in brackets.

* Statistical significance at the $10 \%$ level; ** Statistical significance at the $5 \%$ level; ** Statistical significance at the $1 \%$ level.

The implementation of the compensation system has made the pilot regional government become the right holder for the compensations for ecological damages, and the relevant information about ecological damage needs to be disclosed and reported to the State Council regularly in accordance with the law. Thus, the compensation system has a significant impact on regional environmental supervision in pilot provinces and cities. Local governments not only can claim compensation from those responsible for ecological damage as local governments' fiscal revenue but also fulfil the environmental regulation requirements of the central government, which require polluting enterprises in their jurisdictions to take measures to prevent and control environmental pollution and improve the ecological environment.

\subsubsection{Moderating Effect Test}

This paper examines the moderating effect of market degree, and the results are shown in Table 5. Column (1) does not take into account control variables and fixed effects, and the results are not significant. After adding the control variable, the interaction coefficient in column (2) is significantly positive at the $10 \%$ level. After including the annual effect and the industry effect in column (3), the interaction coefficient of 0.0008 is significant at the level of $5 \%$. That is, after the compensation system, market degree has a moderating effect on corporate environmental investment, and the increase of environmental investment in high-marketization areas is higher. $\mathrm{H} 2$ is verified.

Table 5 Moderating effect of market degree 


\begin{tabular}{|c|c|c|c|}
\hline \multirow[t]{2}{*}{ Variable } & \multicolumn{3}{|l|}{ Invest } \\
\hline & Q1ه & $\mathrm{\nabla 2 \bigotimes}$ & ४3囚 \\
\hline \multirow[t]{2}{*}{ MD } & 0.0001 & -0.0002 & -0.0001 \\
\hline & $(0.35)$ & $(-0.26)$ & $(-0.19)$ \\
\hline \multirow[t]{2}{*}{ Time } & -0.0035 & -0.0029 & -0.0061 \\
\hline & $(-1.04)$ & $(-0.66)$ & $(-0.91)$ \\
\hline \multirow[t]{2}{*}{ MD*Time } & 0.0006 & $0.0006^{*}$ & $0.0008 * *$ \\
\hline & $(1.46)$ & $(1.80)$ & $(2.19)$ \\
\hline \multirow[t]{2}{*}{ Intercept } & -0.0003 & -0.0079 & -0.0093 \\
\hline & $(-0.14)$ & $(-0.47)$ & $(-0.43)$ \\
\hline Controls & NO & YES & YES \\
\hline Year & NO & NO & YES \\
\hline Industry & NO & NO & YES \\
\hline Region & NO & NO & YES \\
\hline Sample size & 138 & 138 & 138 \\
\hline Observations & 552 & 138 & 138 \\
\hline $\mathrm{R}^{2}$ & $2.01 \%$ & $3.68 \%$ & $5.26 \%$ \\
\hline
\end{tabular}

Note. T statistics are shown in brackets.

* Statistical significance at the $10 \%$ level; ** Statistical significance at the $5 \%$ level; ***Statistical significance at the $1 \%$ level.

When environmental supervision is strengthened, the increase in fixed effects in high-marketization areas is significantly higher than that in low-marketization areas. This result can be explained as follows:

Before the compensation system, local governments lacked the motivation for environmental governance, and officials tended to vigorously develop regional economies at the expense of the environment. In high-marketization areas, the level of government intervention is even lower. Enterprises face weak regulatory pressures, and managers tend to allocate more limited resources to productive activities. However, the compensation system clearly stipulated that local governments can obtain compensation for environmental damage, and they should protect the public's right to know about the infraction and subsequent compensation. Environmental protection departments also conduct evaluations; if local officials practice favouritism in their claims work, they will be severely punished. Thus, the compensation system greatly encouraged the regional government to introduce stringent 
regulation and interventions for enterprises, which have a greater impact on the behaviour of enterprises in high-marketization areas, which have always maintained their freedom.

The results of the moderating effect of firm ownership are shown in Table 6 below. As seen, the coefficient of $F O \times$ Time was not significant, indicating that when environmental supervision was strengthened, firm ownership did not have a significant impact on corporate environmental investment; the environmental investment of SOEs was not significantly higher than that of non-SOEs. H3 is rejected.

Table 6 Moderating effect of firm ownership

\begin{tabular}{|c|c|c|c|}
\hline \multirow[t]{2}{*}{ Variable } & \multicolumn{3}{|l|}{ Invest } \\
\hline & Q1ه & ष2】 & $\triangle 3 \rrbracket$ \\
\hline \multirow[t]{2}{*}{ FO } & -0.0002 & -0.0001 & -0.0012 \\
\hline & $(-0.17)$ & $(-0.07)$ & $(-0.09)$ \\
\hline \multirow[t]{2}{*}{ Time } & $0.0014^{\star *}$ & $0.0021^{*}$ & 0.0019 \\
\hline & $(2.01)$ & $(1.80)$ & $(0.82)$ \\
\hline \multirow[t]{2}{*}{ FO*Time } & -0.0004 & -0.0009 & -0.0010 \\
\hline & $(-0.50)$ & $(-0.87)$ & $(-1.01)$ \\
\hline \multirow[t]{2}{*}{ Intercept } & 0.0006 & -0.0015 & 0.0048 \\
\hline & $(1.27)$ & $(-0.09)$ & $(0.25)$ \\
\hline Controls & NO & YES & YES \\
\hline Year & NO & NO & YES \\
\hline Industry & NO & NO & YES \\
\hline Sample size & 138 & 138 & 138 \\
\hline Observations & 552 & 138 & 138 \\
\hline $\mathrm{R}^{2}$ & $1.09 \%$ & $3.66 \%$ & $5.30 \%$ \\
\hline
\end{tabular}

Note. T statistics are shown in brackets.

* Statistical significance at the $10 \%$ level; ** Statistical significance at the $5 \%$ level; ***Statistical significance at the $1 \%$ level.

The result showing that firm ownership has not played a significant moderating effect on corporate environmental investment may have occurred for the following reasons. Since the central government of China is vigorously developing the green economy, enterprises are the micro-subject of ecological civilization construction, and both SOEs and non-SOEs need to assume the main responsibility for 
sustainable development. The implementation of the compensation system has caused local governments to strengthen environmental supervision and restrain the environmental behaviour of enterprises with different types of ownership. Although SOEs are the pacesetters in the construction of a national ecological civilization, they should bear greater environmental responsibility and pressure. However, SOEs have made an important contribution to the performance of local governments at the same time, and they are more favoured by local governments to a certain extent, which can help SOEs avoid the negative impact of environmental regulations. The dual effect of firm ownership explains its nonsignificant moderating effect on environmental investment.

\subsection{Robustness Test}

\subsubsection{PSM-DID}

To eliminate the prior differences between the experimental group and the control group and eliminate the noise of other variables, this paper follows Xu and Yan (2019) and Zang et al. (2020) and uses the propensity score matching method (PSM) to match the new control group and the experimental group. The matching standard includes corporate size, financial leverage, investment opportunities, growth ability, regional economic level, and regional subsidies. The score matching method is a 1:1 match, and the result is shown in Table 7 below. The coefficient of Treated $\times$ Time is significantly positive, indicating that the conclusion of the main effect test is still valid. That is, after the compensation system, corporate environmental investment has been significantly improved.

Table 7 Double differential test after the PSM

\begin{tabular}{lll} 
Variable & \multicolumn{2}{l}{ PSM-DID } \\
\cline { 2 - 3 } & Coefficients & t-value \\
\hline Treated & $-0.0026^{\star \star \star}$ & -3.12 \\
\hline Time & -0.0001 & -0.08 \\
\hline Treated*Time & $0.0018^{\star}$ & 1.66 \\
\hline Intercept & -0.014 & -1.48 \\
\hline Controls & YES & YES \\
\hline Year & YES & YES \\
\hline Industry & YES & YES \\
\hline $\mathrm{R}^{2}$ & $11.24 \%$ & $11.24 \%$
\end{tabular}

Note. * Statistical significance at the $10 \%$ level; ** Statistical significance at the $5 \%$ level; ${ }^{\star \star \star}$ Statistical significance at the $1 \%$ level. 


\subsubsection{Placebo Test}

Taking the impact of other major environmental policies into account, this paper refers to the study of Chen et al. (2015) and Sun (2019) and conducts a placebo test. As the compensation system is a pilot policy, the natural experimental group and control group are defined, and the results of the main effect test have been relatively stable. The improvement in corporate environmental investment is significantly affected by the compensation system rather than other policies and regulations during the same period. In the moderating effect test, the effect of market degree on environmental investment may be a "false fact" due to the fact that exogenous events are not unique. To exclude the abovementioned alternate interpretation, this paper takes the listed companies in the non-pilot areas as a placebo sample. If market degree no longer has an obvious impact on corporate environmental investment in the placebo sample, it means that it is the compensation system that induce the regional government to strengthen environmental supervision, and the level of government intervention suddenly increases in highmarketization areas, resulting in increased corporate environmental investment. The specific test results are shown in Table 8 below. The coefficient of MD $\times$ Time is nonsignificant, largely excluding noise from other policies and regulations during the same period.

Table 8 Placebo tests that exclude interference from other policies and regulations

\begin{tabular}{lllll} 
Variable & Coefficients & Standard error & t-value & P-value \\
\hline MD & $0.0037 * \star *$ & $0.14 \%$ & 2.59 & $0.98 \%$ \\
\hline Time & 0.0013 & $0.12 \%$ & 1.11 & $26.68 \%$ \\
\hline MD*Time & 0.0006 & $0.15 \%$ & 0.45 & $65.57 \%$ \\
\hline Intercept & -0.0020 & $0.90 \%$ & -0.22 & $82.69 \%$ \\
\hline Controls & Yes & Yes & Yes & Yes \\
\hline Observations & 1096 & 1096 & 1096 & 1096 \\
\hline$R^{2}$ & $9.67 \%$ & $9.67 \%$ & $9.67 \%$ & $9.67 \%$
\end{tabular}

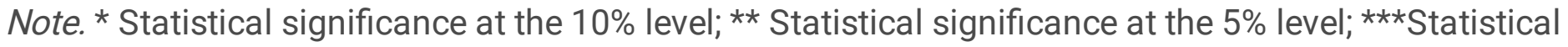
significance at the $1 \%$ level.

\subsubsection{Selection Deviation of Pilot Areas}

Self-selection bias means that the explanatory variable is not random, but the result of individual selection, and this selection process will lead to bias in the estimation of the main effect. As can be seen from Fig. 1 above, before the implementation of the policy, the environmental protection investment level of enterprises in the experimental group, that is, the pilot area, was significantly lower than that of the control group; After the implementation of the policy, the environmental protection investment level of the experimental group and the control group tends to the same level, so the compensation system improves 
corporate environmental investment. However, it can be considered that the significance of the results may be due to the low level of environmental investment of the experimental group. To solve this problem, this paper refers to the paper of Ye (2018), and selects the enterprises with low level of environmental protection investment (lower than the average) in the control group as the new control group for test. If the coefficient is still significantly positive, it shows that the implementation of the pilot policy has indeed improved the environmental protection investment level of enterprises in the pilot area. As shown in Table 9 below, the interaction coefficient is significantly positive at the $1 \%$ level.

Table 9 The robustness test of the new control group

\begin{tabular}{lllll} 
Variable & Coefficients & Standard error & t-value & P-value \\
\hline Treated & 0.0002 & $0.03 \%$ & 0.65 & $51.31 \%$ \\
\hline Time & 0.0001 & $0.03 \%$ & 0.19 & $85.00 \%$ \\
\hline Treated*Time & $0.0013^{\star \star \star}$ & $0.05 \%$ & 2.96 & $0.30 \%$ \\
\hline Intercept & -0.0015 & $1.20 \%$ & -0.42 & $67.59 \%$ \\
\hline Controls & Yes & Yes & Yes & Yes \\
\hline Year & Yes & Yes & Yes & Yes \\
\hline Industry & Yes & Yes & Yes & Yes \\
\hline Region & Yes & Yes & Yes & Yes \\
\hline$R^{2}$ & $3.18 \%$ & $3.18 \%$ & $3.18 \%$ & $3.18 \%$
\end{tabular}

Note. * Statistical significance at the $10 \%$ level; $\star \star$ Statistical significance at the $5 \%$ level; ${ }^{\star \star \star}$ Statistical significance at the $1 \%$ level.

\section{Mechanism Analysis}

This paper analyses the impact of ecological damage compensation system on enterprise environmental protection investment, and puts forward an impact mechanism of the policy on enterprise investment, that is, the policy improves the local government's enthusiasm for environmental governance, strengthens the implementation of environmental protection policy and regional environmental supervision, so as to improve the level of corporate environmental protection investment. In order to verify the above impact mechanism, this paper refers to Li (2013) and Zhang (2016), taking the regional sewage charges as the environmental regulation strength. If the implementation of the pilot policy can improve the regional environmental regulation strength, the impact mechanism has been basically verified. The test results are shown in Table 10 below. After adding control variables and fixed effects, the interaction coefficient in column (3) is significantly positive at the level of $1 \%$, which indicates that the implementation of ecoenvironmental damage compensation system improves the level of regional environmental supervision. 
Table 10 Impact mechanism test

\begin{tabular}{|c|c|c|c|}
\hline \multirow[t]{2}{*}{ Variable } & \multicolumn{3}{|l|}{ Invest } \\
\hline & Q10 & $\mathrm{\nabla 2 \bigotimes}$ & $\triangle 3 \otimes$ \\
\hline \multirow[t]{2}{*}{ Treated } & $0.1984^{\star * *}$ & $0.2869 * \star \star$ & $-0.2831^{\star * \star}$ \\
\hline & (3.19) & (3.27区 & $(-3.12)$ \\
\hline \multirow[t]{2}{*}{ Time } & 0.0118 & 0.2034 & 0.1805 \\
\hline & $(0.38 \rrbracket$ & $(0.88 \otimes$ & $(0.76)$ \\
\hline \multirow[t]{2}{*}{ Treated ${ }^{\star}$ Time } & 0.0192 & $0.0504^{\star \star}$ & $0.0559 * * *$ \\
\hline & $(1.36 \rrbracket$ & (2.11凹 & (3.31) \\
\hline \multirow[t]{2}{*}{ Intercept } & $0.6801 * * *$ & $0.5365^{\star *}$ & $0.7047 * \star \star$ \\
\hline & (3.76) & (2.34) & $(2.75)$ \\
\hline Controls & NO & YES & YES \\
\hline Year & NO & NO & YES \\
\hline Industry & NO & NO & YES \\
\hline Region & NO & NO & YES \\
\hline Sample size & 412 & 412 & 412 \\
\hline Observations & 1648 & 1648 & 1648 \\
\hline R2 & $3.52 \%$ & $40.95 \%$ & $42.08 \%$ \\
\hline
\end{tabular}

Note. * Statistical significance at the $10 \%$ level; $* \star$ Statistical significance at the $5 \%$ level; ${ }^{\star \star \star}$ Statistical significance at the $1 \%$ level.

\section{Discussion And Conclusion}

Due to increasingly serious ecological problems, the intensity of environmental regulation in various countries is increasing, and the effectiveness of environmental policies depends on the decision-making of the "supervisor" -- local government - and the "implementer" - enterprises. This paper regards China's compensation system as an exogenous policy shock and the heavy pollution industry enterprises as the research object and uses a difference-in-differences model for empirical research, answering two questions: $a$. Whether the implementation of the compensation system can strengthen regional environmental supervision, and promote corporate environmental investment? $b$. Does market degree and firm ownership have a moderating effect? The findings are summarized as follows. First, the compensation system can effectively improve CEl. Second, the effectiveness is restricted to market degree. For enterprises in high-marketization areas, the strengthening of local governments' 
environmental supervision has greatly limited their freedom, and the sudden increase in government regulation has also affected them to a greater extent. Third, compared to non-SOEs, for SOEs, the "special status" cannot be used as an "umbrella" to protect them when they cause environmental damage, and both will be treated equally.

\subsection{Theoretical Contributions}

This paper makes the following theoretical contributions. First, this paper examines the impact of external environmental regulation on $\mathrm{CEI}$ and considers the impact of local governments that implement ecological damage compensation policy for the first time, which riches environmental regulation research. A large number of studies explore the role of environmental regulation in promoting corporate technological innovation and measure the intensity of regional environmental supervision with variables such as the pollution removal rate, pollution penalty amount, and government environmental expenditures. These studies have not developed a consensus regarding an authoritative and unified method of measurement for the concept (Jiang 2015; Song et al. 2020). This paper combines theoretical analysis with empirical testing, employs the implementation of a specific policy to represent a change in regional environmental supervision, regards the pilot regional enterprises as a natural experimental group, and accurately identifies the role of regional environmental supervision in promoting environmental investment.

Second, the relevant literature studies the impact of environmental regulation on environmental issues at the national, regional and industry levels without considering environmental regulations at the corporate level, and the results may be influenced by aggregated data (Ren et al. 2018; Swain et al. 2020; Levinson and Taylor 2004). This paper considers macro-environmental policy, RES and micro-enterprise environmental investment in the same scenario, not only to test the implementation effect of the central government policy from local governments but also to prove the effectiveness of environmental protection policy in terms of its effect on enterprises. This paper analyses and verifies the impact of national environmental policy and regional environmental supervision on enterprises and expands the research boundary of environmental regulation theory.

Third, this paper further analyses the moderating effects of market degree and firm ownership, expands research on the effect of environmental regulation on the organizational behaviour of enterprises, and enriches legitimacy theory to a certain extent. The results support the hypothesis that the increase in the environmental investment of enterprises in high-marketization areas is higher because a sudden high government intervention put legal pressure on the enterprises, which caused enterprise to increase their environmental investment to meet external requirements. Interestingly, firm ownership did not play the expected moderating role, which is not consistent with the results of Zhang et al. (2019) and Peng et al. (2020). This paper holds that the dual role of SOEs is the main reason for this difference. Although SOEs are the leading force in the construction of a national ecological civilization, the outstanding contribution made by SOEs to local economic development and their innate legal umbrella have helped them to avoid the negative impact of environmental regulation on their economic interests. In the process of 
constructing an ecological civilization, both SOEs and non-SOEs should assume the main responsibility of sustainable development, and the nature of state ownership should not be a tool for enterprises to circumvent environmental regulation.

\subsection{Policy Implications}

This research has the following three policy implications. First, reasonable environmental regulation can guarantee the effectiveness of local government policy implementation, thus driving enterprises to strengthen environmental protection. However, the externality of $\mathrm{CEI}$, coupled with the local government's pursuit of governing objectives and economic utility, makes it necessary to solve environmental governance problems due to policy constraints at the central government level. The central government needs to formulate scientific and effective policies, apply the "incentive and restraint" method in the compensation system to policy formulation for local governments and various industries, and ensure the supervision and implementation of environmental policies. Second, in the process of constructing an ecological civilization, the central government has gradually increased environmental regulation and paid attention to both incentives and punitive environmental policies. For political, economic and ecological reasons, local governments should implement the central policy strictly and make every effort to change the negative situation of "policies not step forward the South China Sea". Local governments can strengthen environmental supervision by increasing regional pollution penalties and supervising the timeliness and transparency of corporate information regarding environmental impacts. Third, the results of this paper show that market degree strengthens the role of environmental regulation in promoting environmental investment. It is necessary to clarify the advantages and disadvantages of government intervention in enterprises, accelerate marketization reform, give full play to the role of the market in the allocation of resources, and work to optimize the environmental regulation effect.

\subsection{Management Implications}

This research also has several management implications. First, in the context of a series of environmental governance policies and an increase in local government environmental supervision, enterprises need to face more severe penalties for environmental damage. If enterprises want to protect their own economic interests, they must realize legitimacy and put an end to environmental pollution and environmental violations. Second, according to the principle of "who pollutes who governs, who develops who protects", enterprises, as the main users of resources and the main producers of environmental pollution, should make every effort to prevent and control environmental pollution, increase investment in environmental protection projects, disclose environmental information, publicize their environmental protection efforts, and take the initiative to assume primary responsibility for the construction of an ecological civilization.

\subsection{Limitations and Research Prospects}

This paper is subject to a few limitations. First, this paper combines theoretical analysis with empirical testing, innovatively considers the perspective of the policy implementing subject "local government" and 
uses the behaviour of the main environmental body "enterprise" to test the effect of the policy; therefore, there are few directly relevant studies. Second, this paper studies the compensation system and comes to the conclusion that the ecological compensation policy is effective, which may be subject to certain limitations. Follow-up studies should consider testing other ecological damage compensation policies to ensure the generalizability of the results of this paper. Third, due to the availability of data, this paper limits the sample to listed companies in China's heavy pollution industry and does not cover other industries or unlisted companies. Follow-up studies can expand the empirical sample and reverify the conclusion.

\section{Declarations}

\section{Ethics approval}

Not applicable.

\section{Consent to Participate}

Not applicable.

\section{Consent to publication}

Not applicable.

\section{Competing interests}

The authors declare no competing interests.

\section{Conflicts of interest/Competing interests}

The author(s) declared no potential conflicts of interest with respect to the research, authorship, and/or publication of this article.

\section{Availability of data and material}

The datasets used and/or analyzed during the current study are available from the corresponding author on reasonable request.

\section{Code availability}

Not applicable.

\section{Funding}

This research was supported by the Youth Project for National Nature Science Foundation of China (Grant No.71904208), the Major Project for National Natural Science Foundation of China (Grant 
No. 71991483), and the Project of Social Science Achievement Evaluation Committee of Hunan Province (XSP21YBZ168).

\section{Authors' contributions}

$\mathrm{HZ}$ contributed to the conception of the study; CC contributed to the data curation, software, writingoriginal draft preparation; $\mathbf{Y J}$ contributed significantly to analysis and manuscript preparation; QZ helped perform the analysis with constructive discussions.

\section{Acknowledgements}

The authors acknowledge the anonymous reviewers and editors for their helpful guidance on prior versions of the article.

\section{Author Biographies}

- Huixiang Zeng (PhD, Central South University) is a Lecturer in the Department of Accounting at School of Business, Central South University. His research interests include environmental accounting, enterprise environmental disclosure, and corporate social responsibility. He has published in journals such as Journal of Environmental Management, Strategy and the Environment, Sustainability Accounting, Management and Policy Journal, Resources Policy, Corporate Social Responsibility and Environmental Management.

- Chen Cheng (Master, Central South University) is a postgraduate student in the Department of Accounting at School of Business, Central South University. Her research interest is environmental accounting.

- Youliang Jin (PhD, Central South University) is Professor of Accounting at Central South University, China. Her main research interest focuses on resource environmental accounting and management, water resource value assessment and water accounting. She has published in journals such as Business Strategy and the Environment, Journal of Cleaner Production.

- Qiong Zhou (Central South University) is a PhD student in the Department of Accounting at School of Business, Central South University. Her research interest is environmental accounting.

\section{References}

1. Arouri ME, Caporale GM, Rault C, Sova R, Sova A (2012) Environmental regulation and competitiveness: Evidence from Romania. Ecol Econ 81:130-139

2. Bansal P, Roth $K$ (2000) Why companies go green: A model of ecological responsiveness. Acad Manag J 43(4):717-736

3. Bansal P (2003) From issues to actions: The importance of individual concerns and organizational values in responding to natural environmental issues. Organ Sci 14(5):510-527 
4. Baumol WJ (1990) Entrepreneurship: Productive, unproductive, and destructive. J Polit Econ 98(5):893-921

5. Berman E, Bui LT (1998) Environmental regulation and productivity: Evidence from oil refineries. The Review of Economics Statistics 83(3):498-510

6. Chang M, Hu J (2011) Inconsistent preferences in environmental protection investment and the central government's optimal policy. Appl Econ 43(6):767-772

7. Chen T, Harford J, Lin C (2015) Do analysts matter for governance? Evidence from natural experiments. J Financ Econ 115(2):383-410

8. Cull R, Li W, Sun B, Xu LC (2013) Government connections and financial constraints: evidence from a large representative sample of Chinese firms. Journal of Corporate Finance 32(32):1-58

9. Deng F, Jin Y, Ye M, Zheng S (2019) New fixed assets investment project environmental performance and influencing factors-An empirical analysis in China's optics valley. International Journal of Environmental Research Public Health, 16(24). DOl:10.3390/ijerph16244891

10. Eyraud L, Clements BJ, Wane AA (2013) Green investment: Trends and determinants. Energy Policy 60:852-865

11. Fabian N (2015) Support low-carbon investment. NATURE 519:27-29

12. Fang JX (2006) Improvement in the process of marketization and the efficiency of capital allocation. Economic Research, (05):50-61. (In Chinese)

13. Gao X, Zheng H (2017) Environmental concerns, environmental policy and green investment. International Journal of Environmental Research Public Health, 14(12). DOI:10.3390/ijerph14121570

14. Gray WB, Deily ME (1996) Compliance and enforcement: Air pollution regulation in the U.S. steel industry. Journal of Environmental Economics Management 31(1):96-111

15. He X, Ma J, Zhu LN, Li XC (2016) The distortion of the allocation of corrupt entrepreneurial activities. China Industrial Economy, (12):106-122. (In Chinese)

16. Hsueh L (2019) Voluntary climate action and credible regulatory threat: Evidence from the carbon disclosure project. J Regul Econ 56:188-225

17. Jiang L, Lin C, Lin P (2014) The determinants of pollution levels: Firm-level evidence from Chinese manufacturing. Journal of Comparative Economics 42(1):118-142

18. Jiang W (2015) Whether environmental regulation has affected the research and development innovation of Chinese manufacturing enterprises? - Empirical research based on microdata. Journal of Finance Economics 41(02):76-87. (In Chinese)

19. Jiang X, Akbar A (2018) Does increased representation of female executives improve corporate environmental investment? Evidence from China. Sustainability 10(12):1-19

20. Jin Y, Cheng C, Zeng H (2019) Is evil rewarded with evil? The market penalty effect of corporate environmentally irresponsible events. Business Strategy The Environment 29:846-871

21. Joseph T, Mahoney J (1992) Rajendran pandian the resource-based view within the conversation of strategic management. Strateg Manag J 13(5):363-380 
22. Mahoney JT, Pandian JR (1992) The resource-based view within the conversation of strategic management. Strateg Manag J 13(5):363-380

23. Kesidou E, Demirel P (2012) On the Drivers of Eco-Innovations: Empirical Evidence from the UK. Res Policy 41(5):862-870

24. Knellera R, Manderson E (2012) Environmental regulations and innovation activity in UK manufacturing industries. Resour Energy Econ 34(2):211-235

25. Leiter AM, Parolini A, Winner H (2010) Environmental regulation and investment: Evidence from European industry data. Ecol Econ 70(4):759-770

26. Levinson A, Taylor MS (2004) Unmasking the pollution haven effect. Int Econ Rev 49(1):223-254

27. Li HJ (2013) Will corruption damage the quality of environmental policy implementation? Journal of Zhongnan University of economics and law, (6): 34-42. (In Chinese)

28. Li YX, Zeng WQ, Ma Z, Chen KJ (2015) External governance environment, property rights nature and investment efficiency of listed companies. Nankai Business Review 18(01):25-36. (In Chinese)

29. Liao X, Shi X (2018) Public appeal, environmental regulation and green investment: Evidence from China. Energy Policy 119:554-562

30. Liu J (2015) The incentive effect of ecological transfer payments on local government environmental governance - Based on empirical evidence from 46 prefecture-level cities in six eastern provinces. Journal of Finance Economics 41(2):54-65. (In Chinese)

31. Lo D, Frias KM, Ghosh MG (2012) Price formats for branded components in industrial markets: An integration of transaction cost economics and the resource-based view. Organ Sci 23(5):1282-1297

32. Lu HY, Deng TQ, Yu JL (2019) Can financial subsidies promote "greening" of enterprises? Based on research on China's heavily polluted listed companies. Economic Management 41(4):5-22. (In Chinese)

33. Lu YQ, Ling YH (2017) Can green traffic policies affect air quality? Evidence from a difference-indifference estimation in China. Sustainability, 9(6), DOI:10.3390/su9061067

34. Luo DL, Tang QQ (2009) Research on institutional environment and performance of private listed companies in China. Economic Research 44(2):106-118. (In Chinese)

35. Ma WC, Tang YJ (2018) Provincial environmental competition, environmental pollution level and enterprise environmental investment. Accounting Research, (8): 72-79. (In Chinese)

36. Miao XL, Zhao YX (2019) Impact of ecological function area transfer payments on ecological environment improvement: financial compensation or institutional incentives? Journal of Finance and Economics, (05): 17-32. (In Chinese)

37. Peng JY, Xie R, Ma CB, Fu Y (2020) Market-based environmental regulation and total factor productivity: Evidence from Chinese enterprises. Econ Model. DOI:10.1016/j.econmod.2020.03.006

38. Porter ME, DerLinde CV (1995) Toward a new conception of the environment-competitiveness relationship. Journal of Economic Perspectives 9(4):97-118 
39. Qi Y, Chen JW, Li WX, Song PF (2019) Ecological environment management, economic development and public service supply - quasi-experimental evidence from the national key ecological functional areas and their transfer payments. Management World 35(01):115-134 + 227. (In Chinese)

40. Song ML, Wang SH, Zhang HY (2020) Could environmental regulation and R and D tax incentives affect green product innovation? J Clean Prod, 258. DOI:10.1016/j.jclepro.2020.120849

41. Song M, Zhao X, Shang Y, Chen B (2020) Realization of green transition based on the anti-driving mechanism: An analysis of environmental regulation from the perspective of resource dependence in China. The Science of the Total Environment, 698. DOI:10.1016/j.scitotenv.2019.134317

42. Suchman MC (1995) Managing legitimacy: Strategic and institutional approaches. Acad Manag Rev 20(3):571-610

43. Sun M (2019) The effect of border controls on waste imports: Evidence from China's Green Fence campaign. China Econ Rev 54:457-472

44. Swain RB, Kambhampati US, Karimu A (2020) Regulation, governance and the role of the informal sector in influencing environmental quality? Ecological Economics, 173. DOI:

10.1016/j.ecolecon.2020.106649

45. Tang GP, Li LH, Wu DJ (2013) Environmental regulation, industry properties and corporate environmental investment. Accounting Research, (6): 83-89 + 96. (In Chinese)

46. Turken N, Carrillo JE, Verter V (2019) Strategic supply chain decisions under environmental regulations: When to invest in end-of-pipe and green technology. Eur J Oper Res 283(2):601-613

47. Walker K, Zhang Z, Ni NN (2019) The mirror effect: Corporate social responsibility, corporate social irresponsibility and firm performance in coordinated market economies and liberal market economies. Br J Manag 30(1):151-168

48. Wang $H$, Wheeler $D$ (2005) Financial incentives and endogenous enforcement in China's pollution levy system. Journal of Environmental Economics Management 49(1):174-196

49. Wang Y, You J (2012) Corruption and firm growth: evidence from China. China Econ Rev 23(2):415433

50. Wang HP (2018) Analysis of the construction of the system for damages for ecological environment based on foreign experience. Eco-economy 34(09):192-196. (In Chinese)

51. Wei F, Ding B, Kong Y (2017) Female directors and corporate social responsibility: Evidence from the environmental investment of Chinese listed companies. Sustainability, 9(12).

DOI:10.3390/su9122292

52. Xu X, Duan L, Yan Y (2019) The influence of confucianism on corporate environmental investment: Evidence from Chinese private firms. Sustainability, 11(21). DOI:10.3390/su11215941

53. Xu X, Yan Y (2019) Effect of political connection on corporate environmental investment: Evidence from Chinese private firms. Appl Econ Lett. DOI:10.1080/13504851.2019.1693692

54. Yao Y, Zhang MY (2013) Official performance and promotion championships: Evidence from city data. Economic Research 48(01):137-150. (In Chinese) 
55. Ye XQ (2018) Pilot free trade zone and economic growth: An empirical study based on quasi natural experiment. Economic review, (4): 18-30. (In Chinese)

56. Yu B, Shen C (2020) Environmental regulation and industrial capacity utilization: An empirical study of China. J Clean Prod, 246, DOI:10.1016/j.jclepro.2019.118986

57. Zang JN, Liang W, Li ZJ, Wang CY, Wang SY (2020) Does emission trading scheme have spillover effect on industrial structure upgrading? Evidence from the EU based on a PSM-DID approach. Environ Sci Pollut Res Int 27(11):12345-12357

58. Zeng H, Zhang T, Zhou Z, Zhao Y, Chen X (2020) Water disclosure and firm risk: Empirical evidence from water sensitive industries in China. Bus Strategy Environ 29:17-38

59. Zhang H (2016) Strategic interaction of regional environmental regulation: an explanation of the universality of incomplete enforcement of environmental regulation. China's industrial economy, (7): 74-90. (In Chinese)

60. Zhang L, Ren S, Chen X, Li D, Yin D (2020) CEO Hubris and firm pollution: State and market contingencies in a transitional economy. J Bus Ethics 161(2):459-478

61. Zhang Q, Zheng Y, Kong DM (2020) Regional environmental governance pressures, executive experiences and enterprise environmental investments - A quasi-natural experiment based on the Environmental Air Quality Standard (2012). Economic Research, 54(06):183-198. (In Chinese)

62. Zhang WH, Guo YL, Zhang X (2016) Vertical integration, property rights nature and enterprise investment efficiency. Accounting Research, (07):35-41 + 96. (In Chinese)

63. Zhou LA (2004) The incentive and cooperation of government officials in promotion game - On the long-term causes of local protectionism and repeated construction problems in China. Economic Research, (6): 33-40. (In Chinese)

64. Zhou LA (2007) China local officials promotion tournament model study. Economic Research, (07): 36-50. (In Chinese)

65. Zou H, Luan BJ, Zheng XM, Huang JB (2020) The effect of increasing block pricing on urban households' electricity consumption: Evidence from difference-in-differences models. J Clean Prod, 257, DOI:10.1016/j.jclepro.2020.120498

\section{Figures}




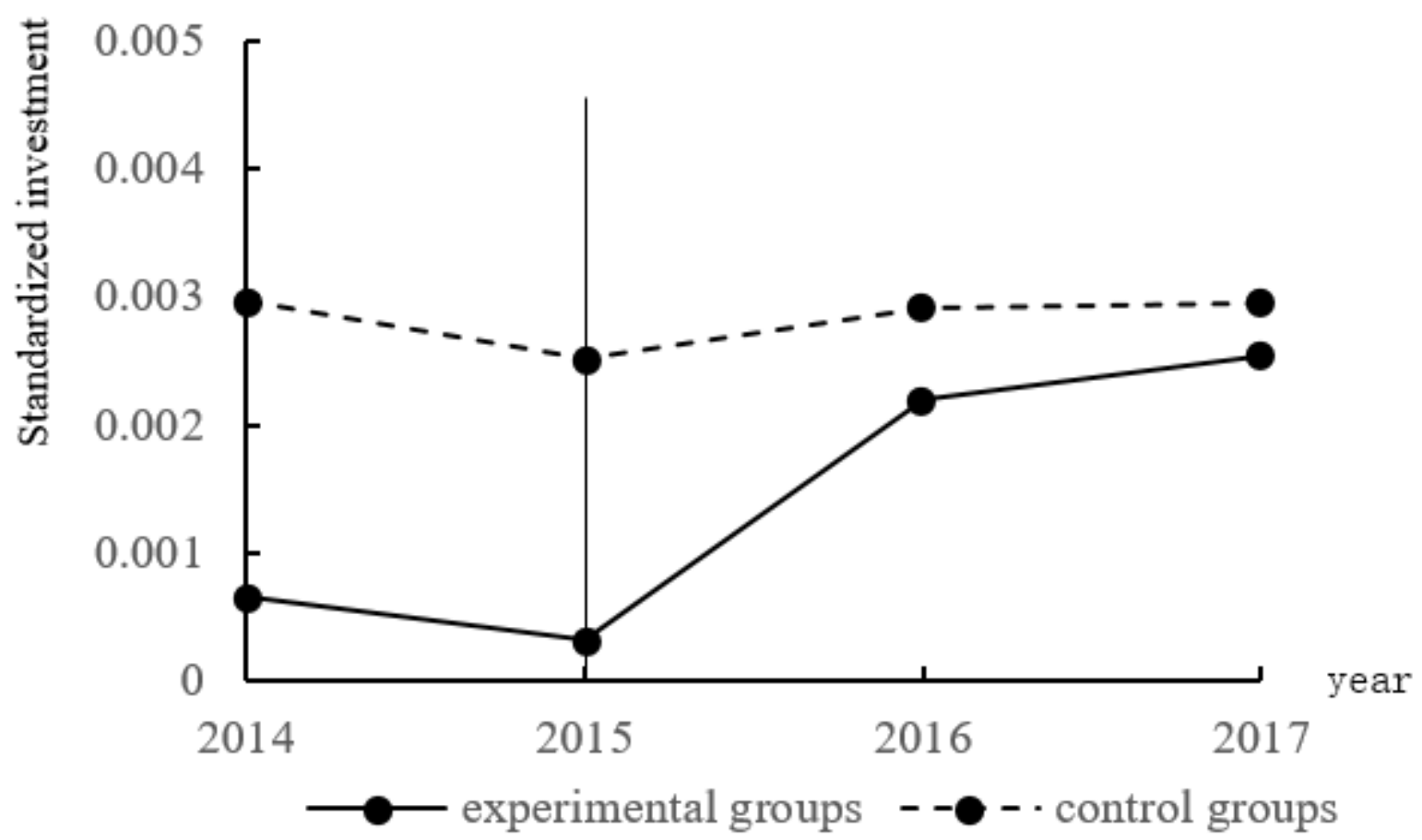

Figure 1

Average CEl in the pilot and non-pilot areas

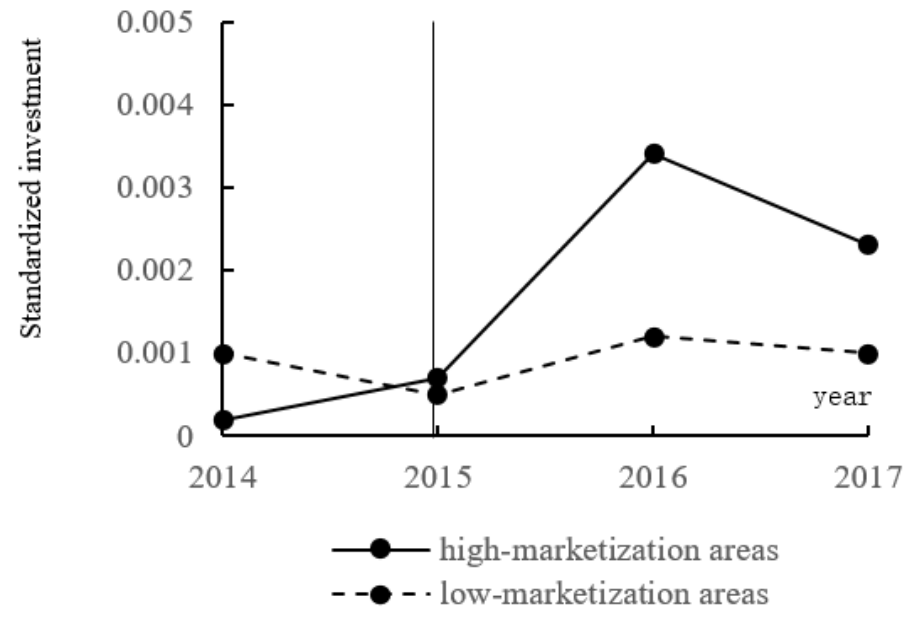

(1) Impact of MD in pilot areas

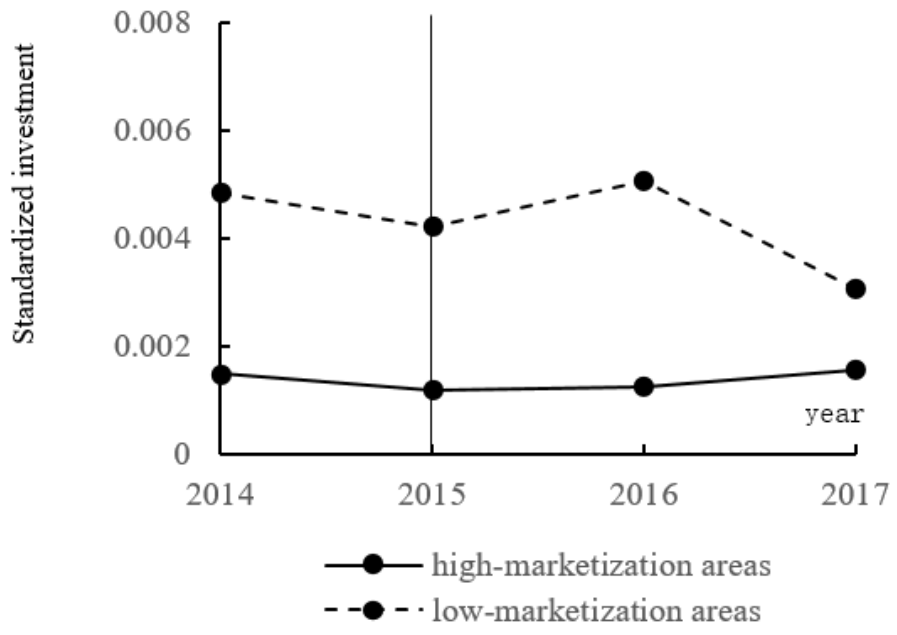

(2) Impact of MD in non-pilot areas

Figure 2

Effect of MD on CEI 


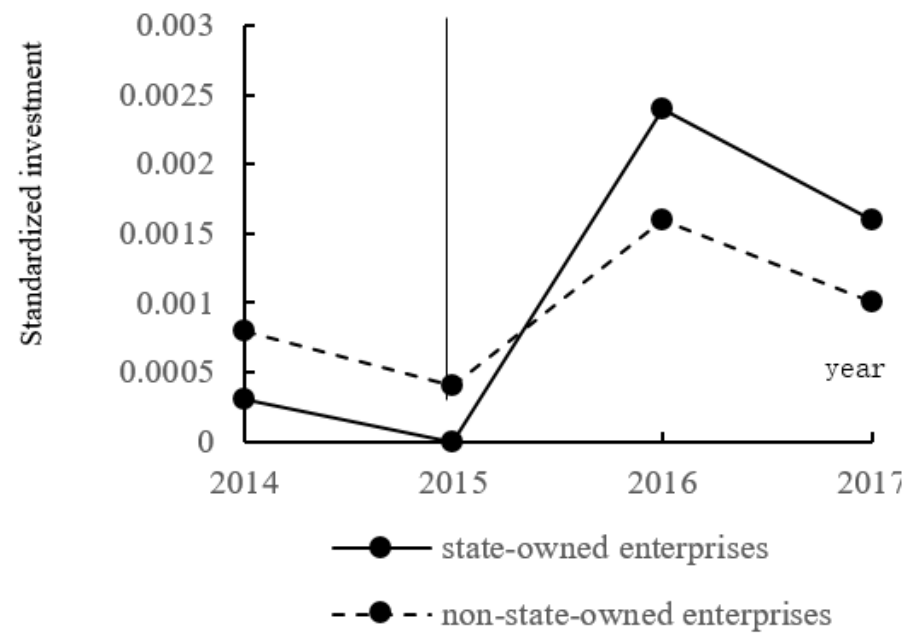

(1) Impact of FO in pilot areas

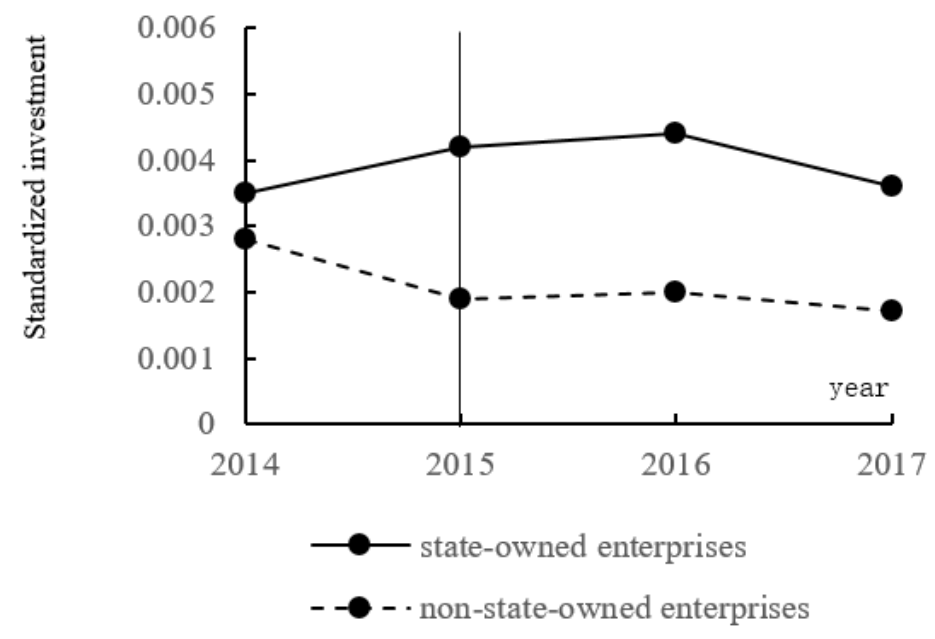

(2) Impact of FO in non-pilot areas

\section{Figure 3}

Effect of FO on CEI 